\title{
Teaching Immigrants Norwegian Culture to Support Their Language Learning
}

\author{
Awal Mohammed Alhassan ${ }^{1} \&$ Ahmed Bawa Kuyini ${ }^{2}$ \\ ${ }^{1}$ Adult Education Unit, $\mathrm{Pb} 1306,1401$ Ski, Norway \\ ${ }^{2}$ School of Education, University of New England, Australia \\ Correspondence: Kuyini Ahmed Bawa, School of Education, University of New England, Armidale, NSW 2351, \\ Australia. Tel: 61-267-733-676. E-mail: kuyinia@une.edu.au
}

Received: December 17, 2012 Accepted: December 25, 2012 Online Published: January 15, 2013

doi:10.5539/ies.v6n3p15

URL: http://dx.doi.org/10.5539/ies.v6n3p15

\begin{abstract}
This study was conducted with 48 adult immigrant students studying Norwegian under basic education program of the Ski Municipality Adult Education Unit between 2009-2011. Using the framework of Genc and Bada (2005), we tried to replicate their study in new setting -Norway. The study investigated migrant students' perceptions learning Norwegian culture and its effects on their learning of the Norwegian language. The participants responded to a set of questionnaire and one open-ended question adapted from Bada (2000) and Genc and Bada (2005). Descriptive statistics and qualitative analysis procedures were used to analyse the data. The results showed that teaching culture to immigrant students raised their cultural awareness of their own and the Norwegian society. It also improved both their language skills and attitudes to the Norwegian culture. The study revealed some similarity between the students' views and the theoretical benefits of a culture class as argued by some experts in the field. The results provide some further evidence of the benefits of learning cultural content as an integral part of learning a new language.
\end{abstract}

Keywords: norwegian, immigrant language learning, teaching language and culture, Norway

\section{Introduction}

The percentage of students with Norwegian as a Second Language (NSL or L2) has been on the increase since 1990s due to the government's commitment to its international obligation in respect of settling refugees and rapid globalisation of the labour market. In recent times, L2 students constitute an appreciable percentage of the population of schools (SSB, 2008). The cohort of students face potential lower academic achievement due in part to limited language skills and therefore represent an at-risk population, who may drop out of school and face a wide range of future challenges (Thompson, 2000; Alhassan \& Kuyini 2012).

The forgoing betrays the fact that students using Norwegian as a second language present a unique challenge to schools and teachers as they strive to support them to learn both the Norwegian language and eventually master academic content in a range of learning areas. Teachers who teach academic subject matter in Norwegian to NSL students are not only teachers of the subject matter, but is also teachers of Norwegian and Norwegian culture. In the regard, teachers need to reflect on and update their practice in order to be able to adequately support the learning of this group of students and help them achieve better academic outcomes.

Genc and Bada (2005) have observed that the dialectical connection between language and culture has always been a concern of L2 teachers and educators and fostered a strong debate with the field. Although that debate was not been settled for decades, Sysoyev and Donelson (2002) and Ivers (2007) allude to the fact that the earlier work by language researchers endorsed the importance and possibilities of including cultural components into L2 curriculum. Pulverness (2003, cited in Genc \& Bada, 2005) claimed that a paradigm shift in the debate occurred in the 1970, with a movement away "...from teaching culture based largely on form and structure to a plurality of approaches..” (p.73)

Some studies from the 1990s, for example Byram (1994a; 1997a) and Kramsch, Cain \& Murphy-Lejeune, 2001) contributed to a better understanding the relationship between learning culture and language. This body of research cemented the very idea that there is an intertwined relation between culture and language and for that matter an indispensable relationship between L2 teaching and target culture teaching (Pulverness, 2003; Piage, 
Jorstad, Siaya, Klien \& Colby, 2003). Thus, there is some level of consensus that culture is a vehicle for language instruction and without the study of culture, teaching L2 is inaccurate and incomplete (Genc \&Bada, 2005). In light of this relationship Bada (2000) concluded, "the need for cultural literacy in $16-20$ +year old students arises mainly from the fact that most language learners, not exposed to cultural elements of the society in question, seem to encounter significant hardship in communicating meaning to native speakers." (p.101). Thus teaching culture as part of language learning is one way of reducing the potential communication difficulty for second language speakers.

The recognition of the critical role of cultural content has led to the evolution of several ways of incorporating culture content in language learning including presenting it as an interdisciplinary core in L2 curricula designs and textbooks (Sysoyev \& Donelson, 2002).

Although the best way to include culture is still unsettled among researchers, there is an acknowledgement of the critical role of students' own motivation and attitudes towards the target language and culture in successful language learning. And Ellis (1994) observes that students' second language learning can be influenced by attitudes towards the target language, the target language speakers and their culture, the social value of learning the second language, and also the students' attitudes towards themselves as members of their own culture (cited in Elyildirim \&Ashton-Hay, 2006, p.1) Such links have also been reported by Clément, Dörnyei and Noels (1994).

\subsection{Problem or Issue of Study}

In Norway, this debate about use of cultural instruction in language teaching has attracted attention in relation to adult immigrants. The literature supports the need for students to study Norwegian culture. This is because, Norwegian unlike English is spoken within a more defined context with specific cultural habits generated and practised over hundreds of years. On the basis of this, the argument about the irrelevance of teaching English culture because English has so many variants and contexts (Alptekin, 2002) does not apply. Adult learners of Norwegian come to the language classes with some more or less fixed and inflexible personal cultural mindset. Their primary cultures have been distilled over time and ingrained in all aspects of their thinking and doing. This implies that in language learning they are more likely to construct and use language on the basis of their primary culture and this may often be at odds with the Norwegian cultural usage. Thus teaching cultural knowledge that allows learners to compare and contrast different cultural interpretations, as part of language teaching will enhance language learning in a more contextualised manner. However, it seems some minority students have negative attitudes towards the Norwegian system including some of the values and ideals, which are also embedded in the school system. The questions to be asked are: how do adults experience cultural content as part of learning Norwegian? What perceptions/attitudes do they have towards learning culture and the target language and in what way does it support their language learning?

\subsection{Purpose of the Study}

The purpose of this study was to describe the social and academic experiences of adult immigrant students on the campus of a traditionally oriented secondary school, their perceptions about the relevance of Norwegian culture to language learning and how these experiences and the school culture promoted or impeded their learning of the Norwegian language to graduation. It is also to examine the contribution of teaching Norwegian culture on immigrants' language learning.

\subsection{Research Questions}

The questions explored by this research were:

1) What are the learning experiences of adult immigrant students in Norwegian School?

2) What role, in the learners' view, has learning culture played in their language learning?

This research is particularly important in relation to the need for policy makers, administrators and secondary schools to reorient language teaching especially for adult immigrants.

\subsection{Literature Review}

The intertwined relation between language and culture, i.e. the interaction of language and culture has long been settled via the works of many philosophers and writers. Prominent among them are Sapir (1962) and Whorf (1956) whose work addressed the notion of "Linguistic Relativity" (Richards, et al., 1992). At the heart of their theory are the ideas that categories and distinctions found in our native language form a strong foundation of how we perceive the world and that cultural differences account for why concepts, words and articulations found in one language may not be found in another language. 
Learning of language requires the development of awareness of the culture and nature of language and its impact on the people who speak the language and live by that culture (Pulverness, 2003; Svalberg, 2007). Such awareness allows us to make references to what we know from our own culture, thereby enriching our language and cultural experiences.

\subsubsection{The Benefits of Teaching Culture in Language Classrooms}

Although the benefits of teaching culture in L2 classes has been broadly accepted and culture has often been taught in language classes, for some decade, the debates about why culture should be taught, what content should be taught and how it could be taught to support learners persisted into 1990s (Kitao, 2000).

Several scholars have acknowledged the benefits of studying culture as part of language learning. Kitao (2000) referencing several authors outlines some of the benefits of including teaching cultural content in language teaching. First, studying culture provides students with a contextualised understanding of the language and this according to (Stainer, 1971) renders the study of L2 meaningful. In deed, gaining an understanding of language as 'open, dynamic, energetic, constantly evolving and personal' betrays the rich complexities of communication to the learner (Shohamy, 2007, p.5).

The second form of benefit revolves around the perspective of learners. The perspective of the learners has to do with conception of the people of the target language and the attitudes to the language itself. In relation to the first, Kitao (2000) observes that one of the major problems in language teaching is that it may sometimes fail to convey that important point that the native speakers of target language are real people. He declares that although grammar books give students so-called genuine examples from real life, without the background knowledge of those real situations, these examples are unlikely to render the native speakers real. Thus providing access to cultural aspects of language would profoundly support students to relate the abstract sounds and forms of a language to real people and places (Chastain, 1971). On the other hand it is important to think of the attitudes learners have towards the language as these drive motivation (Clément, Dörnyei \& Noels, 1994) and it has been observed that studying culture as part of new knowledge changes the attitudes of the learners to the people of the target language (Deaux, Dane \& Wrightsman, 1993).

Thirdly cultural content motivates language learners and early research (Gardner \& Lambert, 1959, 1965, 1972) demonstrated the effect of motivation in the study of L2. In achieving high motivation, culture classes do have a great role because learners can be attracted to culturally based activities such as music dance, role playing, and research on peoples, which appeals to the different learning styles of students. Thus studying culture increases students' curiosity about the society and motivation to master their language skills. In other words studying culture may generate in students a liking of the native speakers of the language, as well as facilitate the students' capacity to learn other subjects including the geography and history of the target culture (Cooke, 1970). Besides, learning culture also contributes to the learning of language and some studies show that there is benefit to language learning deriving from learning culture. In a recent Taiwanese study, Tsou (2005) examined the effect of cultural instruction on foreign language learning. The researcher implemented culture instruction within two elementary EFL classrooms for one semester to see the effects of culture instruction on foreign language learning. The results showed that when lessons were integrated into EFL instruction, students' language proficiency was significantly improved and they had better interests in language learning.

Finally, learning culture as part of language improves the understanding of learners' own culture and those of others. In other words learning another language is a tool for dismissing ethnocentric views, which many people espouse. It fosters attitudes that are essential for living in globalised village where tolerance of difference (religious, cultural and sub-cultural), hinges on understanding other and our own culture. Kramsch (2001) notes that people with ethnocentric views are usually culture bound and therefore have difficulty understanding or accepting people with differing points of view. In order to reduce the potential for conflict when we meet other cultures, an intercultural approach to culture learning is important. The intercultural dimension supports the view that cultural knowledge is fundamental to communicating with other people and therefore critically important. Learning culture in language facilitates learners' understanding of themselves in relation to other cultures and how their own culture shapes perceptions of self, the world, and relationships with others. This goal underpins the contemporary emphasis on 'intercultural' approach to teaching cultural content in language learning. In relation to this, Liddicoat (2005) suggested that the 'intercultural' view implies the transformational engagement of the learner in the act of learning in order to decentre learners from their own culture-based assumptions and to develop an intercultural identity as a result of an engagement with an additional culture. 


\subsubsection{Approaches to Teaching Culture as Part of Language Learning}

McKay (2003) opined that culture influences language teaching linguistically and pedagogically through the semantic, pragmatic, and discourse levels of the language and the choice of the language materials. In respect of language materials, the pedagogical influence has to do with cultural content of the language materials and the making a choice between providing examples from the target culture and from others cultures. Some scholars have argued for the use of cultural content from the target language and the other cultures and this is at the core of the question of what is the best approach to teaching culture.

According to Banks and Banks (2004) integrating ethnic content into the curriculum, can take four levels. These include "contributions approach", the "ethnic additive approach", "transformation approach" and "social action approach". The contributions approach focuses on the contributions of ethnic groups in relations to different domains of life including unique events such as celebrations, foods and customs. According to Banks, the ethnic additive approach reflects diversity of cultures and focuses on content relating to ideas and concepts, and themes in the curriculum but not necessarily integrated it into the existing curriculum. The "transformation and social action approaches) are more attuned to the process of re-constructing the curriculum. In the transformation approach teachers and students explore issues of concern, concepts, themes, and problems from the perspective of diverse groups (Banks, 1993; Stallworth, Gibbons, \& Fauber, 2006). In the social action approach teachers use literature that focuses on different cultural perspectives in relation to ethical decision-making and problem-solving. This allows students to identify social problems and concerns, deduce underlying reasons for ethical decision-making and problem solving from the viewpoints of different cultures. Bieger (1996) and Norton (2001) also observe that integrating multiethnic cultural literature into the curriculum for second language learners, helps students learn about the historical and contemporary cultural workings of difference groups. Such an approach leads to a sense of interconnectedness and community; creating a diverse student population with an attitude of open mindedness (Brown, 2000), mutual respect, an appreciation of cultural difference (Stallworth et al., 2006), and to develop some knowledge of the causes of cultural misunderstanding (Shulz, 2007).

Some have advocated for the use of multiethnic cultural literature in cultural instruction as part of language learning because it enhances students' students ability to discover the intricacies of a language, including history and culture. Anderson (1994) concluded that reading material with identifiable cultural content, through which students encountered characters similar to and different from themselves, enhanced their comprehension, allowed them to analyse deeply and ground their language knowledge.

Many L2 students living in monolingual and monoculture environment become culture-bound individuals who are more prone to making premature and inappropriate value judgments about their as well as other cultures. Such limited cultural knowledge can lead them to consider the people of the target language as peculiar and therefore develop negative attitudes toward both the language and the people. This will in turn, play a de-motivating role in their language learning process. In study about the motivational basis of second and foreign language acquisition using social psychological constructs to the acquisition of English in the unicultural Hungarian setting, Clement, Dornyei and Noels (1994) found, among others, the existence of attitude-based (integrative motives) for language learning. Thus student attitudes to the language and the context of the target language can contribute to effective teaching and learning of second language. And since teachers recognize that all students possess positive and negative attitudes in varying degrees, and that the negative ones can be changed by thoughtful instructional methods, it is important to use materials and activities that help students achieve an "understanding and appreciation of the foreign culture" (Brown 2000, 181). Thus studying another culture is an important means of overcoming the limits of a mono-cultural perspective and reaching the realm of different perspective.

\section{Method}

\subsection{Participants}

The participants in this study were 48 immigrant students studying Norwegian language in Ski Municipality. There were 14 females and 34 males aged between 16-35 years of age and in the final year of G 16-20+ year groups. The participants were all refugees from Iraq, Afghanistan, Ethiopia, Eritrea and Philippines. While the majority $(n=43)$ were first time refugees the rest $(n=5)$ had recently joined their families who migrated earlier. As new comers to the Norwegian society, the participants were all new to the Norwegian culture. The participants attended culture workshops as part of their language learning. The main approach we used to teach cultural content in the course had elements of the four approaches outlined by Banks and Banks (2004) - 
contributions approach", the "ethnic additive approach, "transformation approach" and "social action approach" already summarised in the literature section.

\subsection{Instruments and Data Collection}

One set of Questionnaire (yielding quantitative data) and one open-ended question (providing qualitative data) were used to collect data from participants. The Questionnaire consisted of five items adapted from Bada (2000). This study, as replication of the Genc and Bada (2005) study focused on the following themes: Language skill (Items 1, 2), Cultural awareness (of both native and target culture (Item 3), Attitude towards the target culture (Item 4), and Contribution to the prospective teaching profession (Item 5)

In this study the forth theme focussed on contributions of learning culture on the students attitudes towards the target culture. The open-ended question focussed on what role learning culture play in language learning.

The data for this study was collected between 2009-2011 academic years following the completion of the three weeks culture courses. Students taking this class evaluated the course, responding to the five-item questionnaire adapted from Bada (2000) and Genc and Bada (2005). The first two items required the participants respond to questions about contribution the culture course made to their language skill(s). The item of the second theme investigated participants' cultural awareness resulting from the course and the third theme was concerned with attitude change in the participants towards the target culture.

\subsection{Data Analysis}

The quantitative data were analysed using the SPSS statistical package. Descriptive statistics including frequencies and percentages were obtained. T-tests were conducted to explore the influence of age and gender on participants' responses. On the other hand, the open-ended question was analysed qualitatively, based on the pre-coded themes deriving from the interview questions.

\section{Results}

The results from the quantitative data of the three main themes are presented first, followed by responses from the qualitative data.

\subsection{Theme 1: Cognitive/Language Skill}

Students' responses to the question of whether cultural studies helped their language skills showed that 44 of the $48(91.6 \%)$ participants answered "Yes", indicating that their belief in the positive effect of the course on their language skills (See Table 1 below).

Table 1. Course contribution to language skills

\begin{tabular}{lll}
\hline Response & Frequency & Percent \\
\hline No & 4 & 8.3 \\
Yes & 44 & 91.6 \\
Total & 48 & 100 \\
\hline
\end{tabular}

We also calculated the overall scores for all participants on the three themes. Over all, quantitative data analysis showed that the participants rated the effect of the training as having very good effect on their language (66.7\%). Another $18.8 \%$ of participants rated it as having good effect and the rest (14.6\%) rated it as having little effect (See Table 2).

Table 2. Overall effects of culture learning

\begin{tabular}{lll}
\hline Response & Frequency & Percent \\
\hline Little Effect & 7 & 14.6 \\
Good Effect & 9 & 18.8 \\
Very Good Effect & 32 & 66.7 \\
Total & 48 & 100 \\
\hline
\end{tabular}


Table 3 shows that the speaking skills of the respondents improved by $54.2 \%$. This is mainly due to the fact that the students communicated only in Norwegian during discussions in the cultural class.

Table 3. Area of language skill improvement

\begin{tabular}{lll}
\hline Response & Frequency & Percent \\
\hline Reading & 10 & 20.8 \\
Writing & 2 & 4.2 \\
Listening & 10 & 20.8 \\
Speaking & 26 & 54.2 \\
Total & 48 & 100.0 \\
\hline
\end{tabular}

\subsection{Theme 2: Cultural Awareness}

Under this theme, and as shown in Table 4 the objective of raising cultural awareness was achieved.

Table 4. Raising cultural awareness

\begin{tabular}{lll}
\hline Response & Frequency & Percent \\
\hline No & 12 & 25 \\
Yes & 36 & 75 \\
Total & 48 & 100 \\
\hline
\end{tabular}

\subsection{Theme 3: Attitude towards the Target Culture}

Many immigrant students who have managed very well in school have also had positive attitudes toward the new culture they have become part of. Alhassan and Kuyini (2012) expressed the view that minority students' school achievement is positively related to their adaptation strategies in the new school. Attitude theories suggest that new knowledge contributes to attitudinal evaluation and change. The new knowledge challenges and transforms the existing attitude and as an evolutionary process the individual make a decision. The content of the course was new information that challenged existing information and transformed perceptions. The culture course therefore changed the attitudes of some of the learners.

Table 5 shows that nearly $77 \%$ of the participants said that the course changed their attitude towards the target culture. This implies that the culture course seems to have a positive and perhaps humanizing effect, which aligns with the role of new knowledge in attitude change.

Table 5. Change in attitude towards target culture

\begin{tabular}{lll}
\hline Response & Frequency & Percent \\
\hline No & 11 & 22.9 \\
Yes & 37 & 77.1 \\
Total & 48 & 100.0 \\
\hline
\end{tabular}

\subsection{Theme 4: Contribution to Learning Language}

The aim of this theme was to answer the question: What role does learning culture play in language learning? The responses from the last item of the questionnaire, which was an open-ended question, asked participants if and how the culture class contributed to their learning of Norwegian language. Their responses yielded four subthemes:

- Cultural awareness

- Cognitive load 


\section{- Language skill}

\section{- Internal motivation}

For most of the students, learning about Norwegian culture helped them to relate to ethnic Norwegians and as one of the participants said: "Norwegians are very cold people and full of sceptics ......it is even worse if one does not speak their language very well.....then they take distance and will not even like to talk......"

Another participant continued; “...but if you get to know them very well they are very nice people and they teach you many things............one learns a lot having Norwegian friends.........learning the Norwegian culture is good".

A third participant had this to say: For me my asylum case is still pending I have been in the camp for more than three years and no any positive sign of getting accepted by the immigration....I cant concentrate on learning anything and I have no social life........so I see no point learning about the culture of a society that will not accept me.

\subsubsection{Learning Language is also Learning Culture}

The participants' responses point to the fact that learning language is part of learning culture and vice versa. This accords with Thanasoulas (2001), who concluded that language teaching and learning is culture teaching/learning, and students learning language simultaneously as they learn about culture. This position is well articulated in the study of Genc and Bada (2005) who they link the issue of language learning to the entire process of migration. They observed that the social and political issues surrounding immigration complicate the seemingly basic task of learning a second language. This is also true of the students in this Norwegian context whereby the students realise that in order for them to successfully navigate the Norwegian system at several levels they need to both speak the language and understand the social norms. Culture classes give them the chance to understand these norms and avoid the barriers associate with negative labels that close off doors of opportunity.

\subsubsection{Familiarization with the Target Society}

The respondents stated the program increased their understanding of Norwegian society. One respondent said: "I now understand more about the Norwegian society and why they do some things in some particular ways. I think I am more confident and I can manage on my own and that is what this society is about....to be able to be independent and take up responsibilities.... will be able to answer the questions of my prospective students about Norwegian society"

"I have learnt about identity, freedom, loyalty and the virtue of hard work which are some of the cultural values of this society"... I can communicate with people about cultural topics".

According to Kito (2000), learners lacking insights about the target culture, have difficulty in associating themselves with people in the society and therefore face numerous problems in various forms including motivation to learn the language.

\subsubsection{Learning Grammar}

"I will be able to learn grammar more efficiently.... have realized that learning language is learning how the language is structured and

"I associate language rules to concrete examples ..... I will be able to provide genuine examples from the lives of Norwegian people.

Some participants believe that besides other benefits, a culture class would help them to understand the grammar of the target language. Teachers during the cultural classes cited concrete examples taken from real life situations linked to grammatical structures. This, according to most of the students gave them more understanding of learning grammar.

\section{Enhancing communicative competence in $L 2$}

"Learning culture is also learning about people, this has improved my communicative competence".

"I had the opportunity to use the L2 a lot; thus I feel more confident in speaking Norwegian".

Language learners need more than grammatical skills, they also need communicative competence with linguistic competence and linguistic performance Chomsky (1965) Hymes (1972), Lade (1957). Learners need to know how the native speakers of the language use the language. 


\subsubsection{Expanding Vocabulary}

"We live in this country and should be familiar with the culture and all the cultural codes and values, it will give us new words to enrich our vocabulary"

Most students interviewed explained that cultural knowledge plays a facilitator role in learning new lexical items. Another student had this to say:

"We sing Norwegian folk songs or music learn about Norwegian language and how it was developed and we get new words to make us more articulate in our speaking,,,,,we are able to discuss issues with ethnic Norwegians and that make us proud".

Research in language learning shows that vocabulary acquisition and ability to use these vocabularies appropriately enhance good command of the language.

"The different culture topics introduced me to new vocabulary and different ways of using it in Norwegian.... and this helped me to learn new vocabulary"

Thompson, (2003), observed that studying culture as part of language learning and using mnemonics made learning more concrete. Thus mastery of the language of the host country makes immigrants independent and increases their abilities to cope well in the new society. Many of the participants have to work within the Norwegian society and mastering the language was important because it reduces depended on others. In other words it is beneficial not to have to rely on others to translate all manner communication, when the individual has with others.

\section{Discussion}

The study set out to explore the experiences of the adult learners exposed to a combination of cultural instruction and language learning. Based on theories and research evidence (Banks, 1993, 2004; McKay, 2003; Pulverness; 2003; Stallworth, Gibbons, \& Fauber, 2006; Svalberg, 2007) that suggests that combining cultural content with language instruction improves students' global language skills, the researchers used a range of approaches, including multiethnic content side by side with mainstream Norwegian cultural content.

The results of the study showed that the adult learners were satisfied with the course and reported that the course increased the language skills, especially in terms of reading, speaking and listening, but not writing. In a nutshell, they experienced improved communicative skills and were motivated to learn the language. The respondents also said that studying language helped their vocabulary, grammatical structures and other grammatical items. Such a finding accords with Tsou (2005) who found that Taiwanese students benefited from such cultural immersion in language learning. Their language proficiency was significantly improved. In addition, they had better interests in language learning.

Motivation and attitudes, although difficult to identify, are major factors affecting students' study of a second language. Research on these factors began in the early 1970s and was strongly influenced by Gardner and Lambert's (1972) finding that learners who desire to become like people in a target culture are the most successful in language study. This idea dominated the field and led to numerous follow-up studies based on their work. Although the earlier studies of Gardner and Lambert (1972) were not conclusive, recent research (Clément, et al., 2008; Elyildirim \& Ashton-Hay, 2006) suggests that motivation and attitudes are important in language learning.

The second major finding was that the course raised their awareness of their own and target culture and changed their attitude towards the target culture. Awareness-raising deriving from new knowledge, culminated in the change in attitude toward Norwegian culture, and this aligns with the role of knowledge in attitude change. Theories of attitude change hold that the nature of attitudes towards an object or phenomenon is related to information / knowledge about the object or phenomenon (Deaux, et al., 1993). Attitudes and information therefore affect each other such that, existing attitudes influence the way new information is perceived (Pratkanis \& Greenwald, 1989) and new information can also oppose the evaluations of attitude objects, thereby contradicting the existing beliefs (Chaiken \& Stangor, 1987). The new information from the course therefore had the effect of changing the participants attitudes because raising aware of their own and target culture set in motion, an analysis of the both cultures and reassessment of their attitudes.

\subsection{Implications}

The findings support the idea that Norwegian culture could be studied concurrently with the learning Norwegian language. Further, they imply that adult language learners would benefit immensely from integrating Norwegian and other cultural content, which will allow refugees and perhaps other immigrants opportunity to use their 
language to support a better understanding of the L2. In other words, while integrating Norwegian cultural content helps students to learn Norwegian, the inclusion of multiethnic content also benefits students by allowing them to re-evaluate their own languages with a broader linguistic and cultural lens. Therefore, what is needed in the education of L2 children is the development of Norwegian and maintenance of their native language. As Nichols, Rupley, Webb-Johnson, and Tlusty (2000) have argued, an educational system that bases its expectations, delivery, and curricular content primarily on the norms of the mainstream values and ways is inadequate for educating students of diverse backgrounds. This is because it pushes L2 students to remain torn between two worlds and fails to endorse the notions of diversity, biculturalism and bilingualism as useful community growth resources.

\section{Conclusion}

The study using the framework of Genc and Bada (2005) examined the perceptions of refugee students in Norway about the influence of a culture course on the language skills and attitudes toward the target culture and society. Although the findings mirrored those of Genc and Bada (2005) the differences in context meant that outcomes might not be the same for the participants in this study and those in the 2005 study. However, it supports the conclusion that culture classes have some positive influences on language skills and attitudes to language and a target culture.

In other words a cultural study is significantly important in language learning, raising cultural awareness, changing attitudes towards native and target societies, and contribution to the ones personal development and the Norwegian society at large. It also enabled the students to get to know each other better in terms of socialising, as students were grouped in such a way that each group included students from different classes and different ethnic groups. This study is in line with Bank`s (2004) social action and additive approaches to teaching culture. The respondents in this study felt transformed in their thinking and listed five points as potential contribution of a culture teaching they took part in. There are some implications for this study in terms of a culture class in the curriculum of language teaching departments.

\section{References}

Alhassan, M. A., \& Kuyini A. B. (2012). Minority Students' Perceptions of Schooling and Teachers Quality to Support Their Learning in Norway. World Journal of Education, 2(2), 95-108. http://dx.doi.org/10.5430/wje.v2n2p95

Alptekin, C. (2002). Towards intercultural communicative competence in ELT. ELT Journal, 56(1), 57-64. http://dx.doi.org/10.1093/elt/56.1.57

Anderson, R. C. (1994). Role of the reader's schema in comprehension, learning, and memory. In R. Ruddell, M. Ruddell, \& H. Singer (Eds.), Theoretical models and processes of reading (4th ed., pp. 469-482). Newark, DE: International Reading Association.

Bada, E. (2000). Culture in ELT. Cukurova University Journal of Social Sciences, 6, 100-110.

Banks, J. A. (1993). The canon debate, knowledge construction and multicultural education. Educational Researcher, 22, 4-14.

Banks, J. A., \& Banks, C. A. (2004). Multicultural education: Issues and perspectives (5th ed.). New York: John Wiley \& Sons.

Bieger, E. M. (1996). Promoting multicultural education through a literaturebased approach. The Reading Teacher, 49, 308-312.

Brown, H. D. (2000) Principles of Language Learning and Teaching. White Plains, EUA : Longman.

Byram, M. (1989). Cultural Studies in Foreign Language Education. Clevedon: Multilingual Matters Ltd.

Byram, M. (1997a). Cultural awareness' in vocabulary learning. Language Learning Journal, 16, 51-57.

Byram, M. (Ed.). (1994a). Culture and Language Learning in Higher Education. Clevedon: Multilingual Matters Ltd.

Chaiken, S., \& Stangor, C. (1987). Attitude and Attitude change. In K. Deaux, C. F. Dane, \& S. L. Wrightsman, Social psychology in the 90's. (6 ${ }^{\text {th }}$ ed). Pacific Grove, California: Brooks \& Cole Publishing.

Chandler, D. (1994). The Sapir-Whorf Hypothesis. Retrieved from http://www.aber.ac.uk/media/Documents/short/whorf.html

Chastain, K. (1971). The development of modern language skills: Theory to practice. Chicago: Rand McNally. 
Chomsky, N. (1965). Aspects of the Theory of Syntax. Cambridge, Mass.: MIT Press.

Chomsky, N. (1968). Language and Mind. Harcourt Brace Jovanovich, Inc.

Clément, R., Dörnyei, Z., \& Noels, K. A. (1994). Motivation, self-confidence, and group cohesion in the foreign language classroom. Language Learning, 44, 417-448.

Cooke, M. A. (1970). Suggestions for developing more positive attitude toward native speakers of Spanish. In H. N. Seelye (Ed.), Perspectives for teachers of Latin American culture. Springfield, IL: State Department of Public Instruction.

Corder, S. P. (1981). Error analyses and Interlanguage. Oxford, UK: Oxford University Press.

Davidson, D. (1999). The Philosophy of Donald Davidson. (Ed) Lewis Edwin Hahn. Illinois: Open Court Publishing Company.

Deaux, K. Dane, C. F., \& Wrightsman, S. L. (1993). Social psychology in the 90 's $\left(6^{\text {th }}\right.$ ed.). Pacific Grove, California: Brooks \& Cole Publishing.

Dilthey, W. (1989). Introduction to the Human Sciences: An Attempt to Lay a Foundation for the Study of Society and History. Wayne State University Press.

Elyildirim, S., \& Ashton-Hay, S. (2006). Creating Positive Attitudes Towards English as a Foreign Language. English Teaching Forum, 44(4), 2-21.

Foucault, M. (1994). The Order of Things: An Archaeology of the Human Sciences. USA: Vintage Books.

Gardner, R. C., \& Lambert, W. E. (1959). Motivational variables in second language acquisition. Canadian Journal of Psychology, 13, 266-272.

Gardner, R. C., \& Lambert, W. E. (1965). Language, aptitude, intelligence, and second language achievement. Journal of Educational Psychology, 56, 191-199.

Gardner, R. C., \& Lambert, W. E. (1972). Attitudes and motivation in second language learning. Rowley, Mass.: Newbury House.

Gardner, R. C., \& MacIntyre, P. D. (1993). A student's contributions to second-language learning. Part II: Affective variables. Language Teaching, 26, 1-11

Genc. B., \& Bada, E. (2005). Culture In Language Learning And Teaching. The Reading Matrix, 5(1), 73-84.

Humboldt, K. W. (1876). The heterogeneity of language and its influence on the intellectual development of mankind.

Hymes, D. (1972). Introduction. In Courtney B. Cazden, Vera P. John, \& Dell Hymes (Eds.), Functions of Language in the Classroom. New York: Teachers College Press.

Ivers, J. J. (2007). Metacognition and Foreign Language Cultural Instruction. Journal of Transformative Education, 5, 152. http://dx.doi.org/10.1177/1541344607303618

Kitao, K. (2000). Teaching Culture in Foreign Language Instruction in the Unites States. Retrieved from http://ilc2.doshisha.ac.jp/users/kkitao/library/article/culture.htm

Kramsch, C. (1993). Context and culture in language teaching. Oxford: Oxford University Press.

Kramsch, C. (2001). Language and Culture. Oxford: Oxford University Press.

Kramsch, C., Cain, A., \& Murphy-Lejeune, E. (1996). Why should language teachers teach culture? Language, Culture and Curriculum, 9(1), 99-107.

Liddicoat, A. J. (2005). Culture for language learning in Australian language-in-education policy. Australian Review of Applied Linguistics, 28(2), 1-28.

McKay, S. L. (2003). The Cultural Basis of Teaching English as an International Language. Retrieved from http://www.tesol.org/pubs/articles/2003/tm13-4-01.html. [30.06.2004] Nichols, W. D., Rupley, W. H., Webb-Johnson, G., \& Tlusty, G. (2000). Teachers* role in providing culturally responsive literacy instruction. Reading Horizons, 41(1), 1-18.

Norton, D. E. (2001). Multicultural children's literature: Through the eyes of many children. Upper Saddle River, NJ: Merrill/Prentice Hall. 
Piage, R. M., Jorstad, H. L., Siaya, L., Klien, F., \& Colby, J. (2003) Culture Learning in Language Education: A Review of the Literature. In D. L. Lange, \& R. M. Paige, Culture as the Core: Perspectives on Culture in Second Language Learning. USA, Information Age Publishing.

Pratkanis, A. R., \& Greenwald, A. G. (1989). A socio-cognitive model of attitude structure and function. In K. Deaux, C. F. Dane, \& S. L. Wrightsman (1993), Social Psychology in the 90's (6 ${ }^{\text {th }}$ ed.). Pacific Grove, California: Brooks \& Cole Publishing.

Pulverness, A. (2003). Distinctions \& Dichotomies: Culture-free, Culture-bound. Retrieved from http://elt.britcoun.org.pl/forum/distanddich.htm

Richards, J. C., Platt, J., \& Platt, H. (1992). Dictionary of Language Teaching \& Applied Linguistics. Essex: Longman.

Sapir, E. (1962). Culture, Language and Personality. University of California.

Schulz, R. A. (2007). The Challenge of Assessing Cultural Understanding in the Context of Foreign Language Instruction. Foreign Language Annals, 40(1), 9-26.

Shohamy, E. (2007). Reinterpreting globalization in the multilingual contexts. International Multicultural Research Journal, 1(2), 127-133.

Stainer, F. (1971). Culture: A motivating factor in the French classroom. In C. Jay, \& P. Castle (Eds.), French language education: The teaching of culture in the classroom. Springfield, IL: State Department of Public Instruction.

Stallworth, B. J., Gibbons, L., \& Fauber, L. (2006). It's not on the list: An exploration of teachers' perspectives on using multicultural literature. Journal of Adolescent \& Adult Literacy, 49, 478-489. http://dx.doi.org/10.1598/JAAL.49.6.3

Statistics Norway. (2008). Retrieved from http:www.ssb.no/innvandring_en

Sysoyev, P. V., \& Donelson L. R. (2002). Teaching Cultural Identity through Modern Language: Discourse as a Marker of an Individual's Cultural Identity. Retrieved June 27, 2004, from http://www.actr.org/JER/issue4/11.htm

Thanasoulas, D. (2001). The Importance of Teaching Culture in Foreign Language Classroom. Retrieved from http:// radicalpedagogy.icaap.org/content/issue3_3/7-thanasoulas.html

Thompson, I. (2003). Vocabulary Learning Strategies. Retrieved from http://www.public.asu.edu/ ickpl/learningvocab.htm

Tsou W. (2005). The Effects of Cultural Instruction on Foreign Language Learning. RELC Journal, 36, 39-57, http://dx.doi.org/10.1177/0033688205053481

Whorf, B. L. (1956). Language, Thought, and Reality: Selected Writings of Benjamin Lee Whorf. (Ed) John B. Carroll. Cambridge: MIT Press.

Wittgenstein, L (1999). Philosophical Investigations. (trans. by. G. E. M. Anscombe). Prentice Hall. 